\section{Transplacental transmission: A rare case of Ebola virus transmission}

\author{
Lawrence Okoror, ${ }^{1}$ Abdul Kamara, ${ }^{2}$ \\ Brima Kargbo, ${ }^{2}$ James Bangura, ${ }^{2}$ \\ Mat Lebby ${ }^{2}$ \\ ${ }^{1}$ World Health Organization and \\ Federal University, Oye-Ekiti, Nigeria; \\ ${ }^{2}$ Ministry of Health and Sanitation, \\ Freetown, Sierra Leone
}

\begin{abstract}
During the mid-transmission period of the Ebola virus disease (EVD) outbreak in Sierra Leone, a 19-year-old pregnant woman, who was a petty trader in a health facility in Freetown, noticing no fetal movement for the past 3 days, reported to a health facility. Medical history and laboratory testing showed no abnormalities except that she was positive for sickle cell. She was not known to any surveillance team of having any epidemiological link to EVD case. She was induced with oral medications as well as IV infusion. EVD test showed that the fetus was positive to EVD with a high threshold value of 21, while the woman was negative for EVD with a threshold value of 42. The woman was positive to EVD IgG but negative to EVD IgM by ELISA technique. This is a rare EVD case in the period of medium transmission. We conclude that the woman may have come into contact with a low dose of virus not enough to cause a full blown EVD and that her immune system was able to stop the virus from further replication.
\end{abstract}

\section{Introduction}

The first recognized Ebola virus infection causing the Ebola virus disease (EVD) occurred in South Sudan and caused a significant outbreak in the Democratic Republic of Congo in 1971. ${ }^{1,2}$ The first major outbreak of EVD in West Africa was the one witnessed in 2014, which claimed more than 11000 lives. ${ }^{3}$ Ebola virus belongs to the filoviridae, a group of envelopes, filamentous viruses up to $1000 \mathrm{~nm}$ in length. The fatality rate of the last outbreak in West Africa was rated at $51 \% .{ }^{4}$ The first reported case was in Guinea in 2013 and the possible cases in Sierra Leone and Liberia were presumed to have been taken from Guinea. ${ }^{5}$ These cases were followed by a cluster that appeared in Nigeria.

Sequencing technology has revealed that the virus that caused the West African outbreak is $97 \%$ identical to the Zaire strain that caused earlier outbreak in the Democratic Republic of Congo and Gabon. The natural reservoir of the Ebola virus is unknown, but reports showed that deaths have been reported among non-human primates in location where outbreaks had taken place and they have been linked to hunters consuming meat from dead nonhuman primates, which might be a potential source of cross over to humans. ${ }^{5-8}$ EVD begins with non-specific symptoms such as fever, nausea, headache, chills and abdominal pain. This is followed by viremia and then the virus spreads to several areas of the body, multiple organs are affected, followed by fatigue and muscle pain that could progress to hemorrhage, which is the late stage of the disease with resultant death due to the breakdown of the immune response. There is also the possibility of effective immune response which eventually clears off the virus and leads to patients' recovery. ${ }^{5,9}$ Although the exact mechanism of Ebola virus pathology is not known, the virus replicates in a variety of cells that include macrophages, epithelial cells, hepatocytes, and endothelial cells. The disease may be due to the induction of high level of chemokines, as well as cytokines, that results in pathological responses, ${ }^{10-12}$ especially in the early phase of infection with the suppression of the alpha/beta interferon which originally inhibit viral dissemination. There have been reports that poor cellular immune response and low levels of antiEbola IgG are responsible for fatal infections. ${ }^{13-15}$ Although all these mechanisms are not well understood, in the current outbreak in West Africa, there are serious concerns about the pathology of the Ebola virus as it seems further away from current understanding. Hence, several studies have been undertaken to better understand the pathology of the virus, such as the persistence study, but a greater knowledge of the pathology of the virus is needed. We report a rare case of EVD that need more understanding, during the medium transmission of the last EVD outbreak in West Africa. We assume that this case report is the first in its kind in recent EVD outbreaks.

\section{Case Report}

A 19-year-old pregnant woman, who was a petty trader in a health facility, referred to a health facility in Freetown (Sierra Leone) with complaints about not noticing fetal movement in the last 3 days. She was pregnant for the first time and in the 36 weeks of gestation. With the clinical
Correspondence: Lawrence Okoror, Department of Microbiology, Federal University, Oye-Ekiti, PMB 373, Oye-Ekiti, Nigeria.

Phone: +2348035316548

E-mail: lawrence.okoror@fuoye.edu.ng

Key words: EVD, fetus, still birth, IgG, IgM, PCR.

Contributions: AK; Was the National Laboratory Manager, he monitored all analysis in the laboratory and was also the lead in the meeting to discuss the outcome of the case and all the recommended confirmatory tests. BK; The Chief Medical Director who approved all the test to be carried out, he personally participated in the laboratory analysis to ensure there is no mix up of samples especially during the re-testing to confirm the results. JB; The Field Epidemiologist Lead, who monitored the case investigation and also contributed to case analysis. ML; The Director of Health Laboratories, who contributed to laboratory analysis especially during the retesting of the case, monitored movement of samples personally and was involved in result interpretation. LO; Was the Field Epidemiologist that handled case investigation, later became WHO national laboratory team lead. He monitored sample collection, ensured that the right samples were analyzed and interviewed the case. While WHO national laboratory team lead was involved in laboratory results interpretation from the beginning to the conclusion, he also wrote the paper with Abdul Kamara.

Conflict of interest: the authors declare no conflict of interest.

Funding: none.

Dedication: this article is published in loving memory of Dr Abdul Kamara with whom we did this work, before his demise. It was his wish to see this article published in a reputable journal though he is not here with us to witness it. May his gentle soul rest in perfect peace.

Received for publication: 18 April 2018.

Revision received: 18 June 2018.

Accepted for publication: 19 June 2018.

This work is licensed under a Creative Commons Attribution-NonCommercial 4.0 International License (CC BY-NC 4.0).

(C) Copyright A. Kamara, et al., 2018 Licensee PAGEPress, Italy

Infectious Disease Reports 2018; 10:7725 doi:10.4081/idr.2018.7725

information of not noticing fetal movement, she was induced using oral medication and IV lines inserted for fluids. Induction occurred for several hours and she was delivered a dead baby. The placenta did not 
show any noticeable abnormalities but the dead child was heavily macerated. The placenta was discharged and later incinerated according to the standard clinical procedure. The safe and dignified burial team was called, swabbed the dead baby and the sample was transported to the nearest laboratory for EVD testing. The nurses who engaged the patient realized a full personal protective equipment. The surveillance team was called in to investigate the case.

\section{Clinical picture of the mother}

Prior to delivery, the woman clinical picture looked normal other than the in utero deceased baby as indicated by the ultra sound scan. She had no fever, no vomiting and no diarrhea. PCV and blood pressure were also normal for the gestation period. After the commencement of the induction, she experienced a small amount of vomiting, which could be related to the induction processes. After delivery, she was still normal, with no bleeding and no other issues. She was discharged home with medication (amoxicillin and flagyl). She was reported to have a history of sickle cell anemia. The placenta was discharged and then incinerated (standard procedure).

\section{Surveillance report}

The pregnant woman was not known to any team member and did not come from a contact list or quarantine home and was not sought in connection with any cluster. Discussions ensued after the morning meeting, with the agreement of going to the clinic to commence investigations. The Contact Tracing Mentor telephoned to state that the woman had returned to the clinic and she has agreed to speak with the surveillance team. The woman returned because she forgot to take her discharge medications and not for any complication. The staff, knowing of the positive result of the swab, kept her at the clinic in the isolation unit. She remained in good health. She was well, alert, sitting up strongly, and speaking normally. She was symptom-free - no fever, no bleeding, no vomiting, no aches and pains etc. She did not meet the EVD case definition and she agreed to be interviewed with a hospital staff, contact tracer and WHO team. The interviewers wore personal protective equipments and maintained a distance of $1 \mathrm{~m}$ at all times. No materials were exchanged.

She did not report any travel history. She did not report any knowledge of other cases, or of having any sick people at her home. She denied having attended any funeral. The father of the child was reported to be a casual trader. The woman reported that she had not really seen him since the conception. Effort was made to contact him with a view to interviewing him to determine any similarities or contradictions with woman's story.

\section{Laboratory results}

The swab from the baby was taken to the nearest laboratory and it returned positive to direct qPCR with CT value of 21 ; this was again taken to another laboratory for confirmation and it also returned a positive qPCR test of 21.5 threshold. The woman was invited for sampling and a qPCR test reported negative with a CT value of 42 . Her blood samples were taken for serology and returned IgM negative and IgG positive using the competitive ELISA technique which was carried out in the Chinese laboratory in Jui Freetown.

\section{Discussions and Conclusions}

The major concern of this rare type of $\mathrm{EV}$ infection is the high viral load in the fetus while the mother was negative. We try to explain this by using several hypotheses. We are aware that the virus replicates faster in newborns than in adults, which may explain the high viral load in the fetus while the mother remains negative. The mother could have come into contact with the virus at a very low dose (not infection dose) and maternal immune response was able to stop further viral replication, while the virus crossed the placenta to infect the fetus. In the fetus, the virus replicates at a very fast rate which then killed him. This is further explained by the circumstance that the mother was positive $\mathrm{IgG}$, which confirms that at one time, she came into contact with the virus, since there is no other way in which the fetus could have become infected. The mother may have developed IgM which are early antibodies that later give way to EV-IgG. A reason for the maceration of the fetus could be explained by the fact that the fetus could have been infected a few days before delivery and also died few days before delivery - at a time enough for the mother's IgM to give way for EV anti-IgG, which explains why the mother was $\operatorname{IgG}$ positive and IgM negative. Since IgM do not cross the placenta, there was enough time for fetal infection before the production of $\operatorname{IgG}$ that crosses the placenta. However, before the production of IgG, the fetus would have been infected and due to the rapid replication of the virus, he would have been left without protection of maternal antibodies; hence IgG becomes noneffective even when produced. Although some reports ${ }^{13,14,15}$ indicate that anti-EV IgG are produced at low level, they were not enough to offer any protection.

The fact that the mother had a sickle cell disease could also partially explain why the virus could not replicate quickly in her, thus enabling the virus's immune response to be cleared. Several authors have reported low prevalence of viral infections in individuals with sickle cell. Sergie et al. ${ }^{16}$ reported a low prevalence of HIV in individuals with sickle cell and attributed this to the low cellular iron and oxygen regulation.

Although there have been various reports of transplacental transmission of viruses, this type of transmission has not been reported. Mims ${ }^{17}$ in a review reported several viruses involved in transplacental transmission, but most of them had some notable maternal symptoms, which is different from the case in this report ${ }^{18,19}$ Despite all these reports, none described such a pattern of Ebola virus transmission as in the case here described.

\section{References}

1. Centers for Disease Control and Prevention (CDC). Outbreaks chronology: Ebola hemorrhagic fever. Atlanta, GA: CDC. Updated 26 Mar 2014. [Accessed 28 Mar 2014]. Available from: http://www.cdc. gov/vhf/ebola/ resources/outbreak-table.html

2. Peters CJ, LeDuc JW. An introduction to Ebola: the virus and the disease. J Infect Dis 1999;179

3. WHO. Ebola Situation Report - 30 March 2016. Ebola virus disease outbreak. 2016. Available at: http://apps.who.int/ebola/current-situation/ebola-situation-report-30-march2016

4. Park DJ. Ebola virus epidemiology, transmission, and evolution during seven months in Sierra Leone. Cell 2015;161:1516-26.

5. Bagcchi S. Ebola haemorrhagic fever in west Africa. Lancet Infect Dis 2014; 14:375.

6. Formenty P, Boesch C, Wyers M, et al. Ebola virus outbreak among wild chimpanzees living in a rain forest of Cote d'Ivoire. J Infect Dis 1999;179:S120-6.

7. Georges AJ, Leroy EM, Renaut AA, et al. Ebola hemorrhagic fever outbreaks in Gabon, 1994-1997: epidemiologic and health control issues. J Infect Dis 1999; 179:S65-75.

8. Leroy EM, Souquiere S, Rouquet P, Drevet D. Reemergence of Ebola haemorrhagic fever in Gabon. Lancet 2002; 359:712.

9. World Health Organization. Ebola virus 
haemorrhagic fever in Gabon/The Republic of the Congo-update 22. WHO Disease Outbreak Report. World Health Organization, Geneva, Switzerland. 2002.

10. Baize S, Leroy EM, Georges-Courbot $\mathrm{MC}$, et al. Defective humoral responses and extensive intravascular apoptosis are associated with fatal outcome in Ebola virus-infected patients. Nat Med 1999;5:423-6.

11. Busico KM, Marshall KL, Ksiazek TG, et al. Prevalence of immunoglobulin G antibodies to Ebola virus in individuals during an Ebola virus outbreak, Democratic Republic of the Congo, 1995. J Infect Dis 1999;179:S102-7.

12. Gupta M, Mahanty S, Ahmed R, Rollin PE. Monocyte-derived human macrophages and peripheral blood mononuclear cells infected with Ebola virus secrete MIP-1alpha and TNFalpha and inhibit poly-IC-induced IFNalpha in vitro. Virology 2001;284:20-5.

13. Hensley LE, Young HA, Jahrling PB, Geisbert TW. Proinflammatory response during Ebola virus infection of primate models: possible involvement of the tumor necrosis factor receptor superfamily. Immunol Lett 2002;80: 169-79.

14. Villinger F, Rollin PE, Brar SS, et al. Markedly elevated levels of interferon (IFN)-gamma, IFN-alpha, interleukin (IL)-2, IL-10, and tumor necrosis factor-alpha associated with fatal Ebola virus infection. J Infect Dis 1999;179: S188-191.
15. Gupta M, Mahanty S, Greer P, et al. Persistent Infection with Ebola Virus under Conditions of Partial Immunity. J Virol 2004:958-67

16. Nekhai S; Kumari N; Dhawan S. Role of Cellular Iron and Oxygen in the Regulation of HIV-1 Infection. Future Virol 2013:301-31.

17. Mims CA. Vertical Transmission of Viruses. Microbiol Rev 1981;45:26786.

18. Rombaldi RL, Serafini EP, Mandelli J, et al. Transplacental transmission of Human Papillomavirus Virol J 2008; 5:106.

19. Zgura AF, Ratil E, Vladareanu S. Transplacental Transmission of Human Papillomavirus. J Clin Med 2015;10: 159-62. 